\title{
The Neurobiology and Genetics of Suicide and Attempted Suicide: A Focus on the Serotonergic System
}

\author{
J. John Mann, M.D., David A. Brent, M.D., and Victoria Arango, Ph.D.
}

\begin{abstract}
Numerous abnormalities have been found in the serotonergic system in suicide attempters and completers. There is considerable evidence that the serotonergic system is partly under genetic control and that as yet unknown genetic factors mediate the risk for suicidal behavior independently of the genetic factors responsible for the heritability of major psychiatric conditions associated with suicide. An argument is made that there is a relationship of genetic variants to intermediate phenotypes, such as
\end{abstract}

impulsivity, psychomotor change, pathological aggression and biological abnormalities including specific gene products. A variety of biological indices have been generated by new approaches using postmortem tissue and in vivo imaging that will provide a rich substrate for further genetic studies. [Neuropsychopharmacology 24:467477, 2001] (C) 2001 American College of Neuropsychopharmacology. Published by Elsevier Science Inc.
KEY WORDS: Suicide; Suicide attempt; Candidate genes; Serotonin; Neuro-receptors

Major depression and suicidal behavior are independently related to altered serotonergic function (Mann and Stanley 1986). See Table 1 for a summary (Malone and Mann 1993; Owens and Nemeroff 1994; Stoff and Mann 1997; Mann 1998). In major depression there are fewer platelet serotonin transporters (5-HTT), lower CSF 5-HIAA (Mendels et al. 1972; Sjöström and Roos 1972; Ashcroft et al. 1973a, 1973b; Post and Goodwin 1974; Bowers 1974; Goodwin and Post 1977; van Praag and de Haan 1979; Koslow et al. 1983; Åsberg et al. 1984; Gerner et al. 1984; Roy et al. 1985; Redmond et al. 1986), as well as a reduced growth hormone (GH) re-

From the Department of Neuroscience (JJM,VA), New York State Psychiatric Institute, Department of Psychiatry, Columbia University, New York, NY, USA; Department of Psychiatry (DAB), University of Pittsburgh, Pittsburgh, Pennsylvania, USA

Address correspondence to: J. John Mann, M.D., 1051 Riverside Drive, Box 42, New York, NY 10032, USA. sponse to 5-hydroxytryptophan (5-HTP) (Upadhyaya et al. 1991) and a blunted prolactin (PRL) response to oral fenfluramine (Siever et al. 1984; Coccaro et al. 1989; O'Keane and Dinan 1991; Mann et al. 1992) and to intravenous L-tryptophan (Heninger et al. 1984; Cowen et al. 1990; Price et al. 1991; Upadhyaya et al. 1991). The antidepressant efficacy of selective serotonin reuptake inhibitors (SSRIs) suggests the abnormality in depression probably includes impaired serotonergic function, because selective enhancement of serotonergic activity is therapeutic (Åsberg et al. 1986a). Depletion of serotonin by parachlorophenylalanine (PCPA) (Shopsin et al. 1976) or by reduction of brain tryptophan (Delgado et al. 1990), quickly reverses the antidepressant effect of serotonergic medication in patients (Åsberg et al. 1986a), suggesting that sustained enhancement of serotonergic function is a necessary requirement to sustain this SSRI-mediated antidepressant effect. It seems that the abnormality in serotonergic function may be a biochemical trait, because a blunted prolactin response to fenfluramine and a vulnerability to depression in response to tryptophan depletion are present during the 
Table 1. Evidence for Independent Serotonergic Abnormalities in Association with Major Depression and Suicidal Acts

\begin{tabular}{|c|c|c|}
\hline Presynaptic Indices & Major Depression & Suicide/Suicide Attempts \\
\hline CSF 5-HIAA & $\downarrow$ & $\downarrow$ \\
\hline \multicolumn{3}{|l|}{ Serotonin transporter } \\
\hline Platelets & $\downarrow$ & $\mathrm{NC}$ \\
\hline \multirow[t]{2}{*}{ Brainstem } & $\downarrow$ & $\downarrow^{a}$ \\
\hline & $\downarrow$ & $\downarrow$ \\
\hline Prefrontal cortex & (Dorsal and ventral) & (Only ventral?) \\
\hline \multicolumn{3}{|l|}{ Postsynaptic receptors } \\
\hline $5-\mathrm{HT}_{2 \mathrm{~A}}$ & $\downarrow$ & $\uparrow$ \\
\hline \multicolumn{3}{|l|}{ Transmission } \\
\hline \multicolumn{3}{|c|}{ Prolactin response to serotonin } \\
\hline Fenfluramine & $\downarrow^{a}$ & $\downarrow$ \\
\hline Tryptophan & $\downarrow$ & - \\
\hline \multicolumn{3}{|l|}{ Growth hormone } \\
\hline 5-HTP & $\downarrow$ & $\downarrow$ \\
\hline \multicolumn{3}{|l|}{ Antidepressants } \\
\hline & SSRIs effective & Lithium effective \\
\hline & Reversal by 5-HT depletion ${ }^{b}$ & - \\
\hline
\end{tabular}

period of remission between episodes (Flory et al. 1998). An intermorbid biological abnormality or trait implies a genetic or developmental origin, although enduring illness or treatment effects cannot be ruled out.

Lower serotonergic activity is also independently associated with suicidal behavior. We have hypothesized that there is a serotonergic abnormality contributing to the diathesis or vulnerability for suicidal acts (Mann 1998). Lower levels of CSF 5-HIAA (Åsberg et al. 1986b) and a blunted prolactin response to fenfluramine (Mann et al. 1992) correlate with the presence and lethality of past suicide attempts in patients with major depression and can predict future suicide or suicide attempts (Roy et al. 1989; Träskman-Bendz et al. 1992; Nordström et al. 1994). The association between suicide attempts and low CSF 5-HIAA has also been reported in schizophrenia and personality disorders, indicating that this association is independent of diagnosis. Lower brainstem serotonin (5-HT) and/or 5-hydroxyindoleacetic acid (5HIAA) levels, and alterations in binding kinetics of a number of serotonin receptor subtypes are reported postmortem in the brain of suicide victims compared with nonsuicides (see Arango and Mann 1992; Arango and Underwood 1997 for a review), including the 5-HTT (Stanley et al. 1982; Meyerson et al. 1982; Crow et al. 1984; Paul et al. 1984; Owen et al. 1986; Arató et al. 1987; Arora and Meltzer 1989; Lawrence et al. 1990a, 1990b; Arora and Meltzer 1991; Arató et al. 1991; Laruelle et al. 1993; Mann et al. 1996), and these findings seem to be independent of psychiatric diagnosis (Mann et al. 1989; Arango and Mann 1992). Changes in 5-HTT and 5-HT $1 \mathrm{~A}$ binding in suicide victims are most pronounced in the ventral prefrontal cortex (Arango et al. 1995a), an area involved in behavioral inhibition. Impulsive, aggressive behaviors are more common in suicide attempters (Barratt 1965; Weissman et al. 1973; Mann 1995; Fulwiler et al. 1997), and also correlate with lower serotonergic activity, consistent with a common, underlying, disorder of inhibition or restraint. In rodents and primates, aggressiveness is increased after inhibition of serotonin synthesis or in association with lower serotonergic activity (Vergnes et al. 1986; Molina et al. 1987; Higley et al. 1992). Ventral PFC dysfunction, including impaired serotonergic input, may form part of the diathesis for both impulsive aggression and suicide (Mann 1995).

Independently transmitted genetic factors partly explain the risks for major depression (Gershon 1990) and for suicide (Roy 1993; Roy et al. 1995). Adoption and family studies indicate that suicidal acts have a genetic contribution in terms of cause or diathesis that is independent of the heritability of major psychiatric disorders (Schulsinger et al. 1979; Egeland and Sussex 1985; Roy 1986; Roy et al. 1991; Brent et al. 1996). The data from twin studies (Roy 1993) show a much higher concordance rate for monozygotic (MZ) than for dizygotic (DZ) twins ( $13.2 \%$ vs. $0.7 \%)$, strongly supportive of a genetic component in suicidal behavior. The rate of suicide in DZ twins, although lower than for MZ twins, is over threefold higher than the expected rate of $0.2 \%$. Roy and colleagues (Roy et al. 1995) also found a higher rate of concordance for suicide attempts in $\mathrm{MZ}$ as compared to DZ twins surviving the co-twin's suicide. The rate of concordance for attempted suicide $(38 \%)$ was higher than for completed suicide (13.2\%), indicating attempted and completed suicide are both heritable components of the phenotype of suicidal behavior. The 
largest published twin study (Statham et al. 1998) found a concordance rate for a serious suicide attempt in $\mathrm{MZ}$ twins (23.1\%), to be over 17 -fold greater than the risk compared to the total sample. The heritability for serious suicide attempts was $55 \%$.

Identification of the responsible genes can involve a general survey of the entire human genome. An alternative approach is to identify such candidate genes as those related to the serotonergic system. Genetic factors affecting psychopathology, including suicide risk may operate through effects on serotonergic activity, because of the heritability of serotonin function (Higley et al. 1996) (see Ishikawa et al. 1989; Higley et al. 1992 for a review). Preliminary results are promising. Suicidal acts and serotonergic indices, such as CSF 5-HIAA and the prolactin response to fenfluramine, are associated with an intronic polymorphism (a genetic variant in a noncoding part of the gene) in the gene for tryptophan hydroxylase (Mann et al. 1997; Jönsson et al. 1997; Nielsen et al. 1998; Manuck et al. 1999), the rate limiting biosynthetic enzyme for serotonin. Other candidate genes, such as for the $5-\mathrm{HT}_{1 \mathrm{~A}}, 5-\mathrm{HT}_{2 \mathrm{~A}}$, and $5-\mathrm{HT}_{1 \mathrm{~B}}$ serotonin receptors, and the serotonin transporter (5-HTT), are suggested by the specific serotonergic abnormalities observed in major depression and in individuals with a history of serious suicidal acts or suicide (see Malone and Mann 1993; Mann 1998 for review).

Substance abuse or alcoholism have been associated with high rates of suicide, suicide attempts, and aggression as well as with dysfunction of the central serotonergic system (Ballenger et al. 1979; Virkkunen et al. 1994). Genetic factors play a role in alcoholism (Schuckit et al. 1985) and major depression (Gershon et al. 1989) but their precise identity is unknown. Again the serotonergic system may play a role. It has been suggested that the risk for suicidal behavior, aggressive acts, alcoholism, and substance abuse have, in part, a common underlying genetic or biological predisposition mediated by serotonergic activity (Mann 1998). It should be noted that if a considerable amount of the variance in serotonergic activity is attributable to genetic factors (heritable paternal variance is $37 \%$ and heritable maternal variance is $22 \%$; see (Higley et al. 1993). Thus, there remains considerable potential for such environmental factors as diet and early rearing experiences to influence serotonergic activity.

\section{The 5-HT ${ }_{1 \mathrm{~B}}$ GENE AND RECEPTOR IN SUICIDAL BEHAVIOR}

Aggressive behavior and increased alcohol and cocaine intake have been reported in $5-\mathrm{HT}_{1 \mathrm{~B}}$ receptor gene knockout mice (Saudou et al. 1994; Crabbe et al. 1996; Ramboz et al. 1996; Rocha et al. 1998). In a more recent study (Crabbe et al. 1999), the increased alcoholism in the 5- $\mathrm{HT}_{1 \mathrm{~B}}$ knockout could not be confirmed in different laboratories using standardized methods, either because the original finding was incorrect, attributable to genetic drift in the mice, or for other technical reasons. Nevertheless, this mouse model suggests that functional variants in the $5-\mathrm{HT}_{1 \mathrm{~B}}$ receptor gene may contribute to such human psychopathologies as suicide, aggression, major depression, alcoholism, or substance abuse. There are two human 5- $\mathrm{HT}_{1 \mathrm{~B}}$ receptor subtypes: $5-\mathrm{HT}_{1 \mathrm{~B}}\left(5-\mathrm{HT}_{1 \mathrm{D} \beta}\right)$ and $5-\mathrm{HT}_{1 \mathrm{D}}\left(5-\mathrm{HT}_{1 \mathrm{D} \alpha}\right)$ (Hamblin and Metcalf 1991; Levy et al. 1992; Weinshank et al. 1992; Demchyshyn et al. 1992). The 5- $\mathrm{HT}_{1 \mathrm{D}}$ and 5- $\mathrm{HT}_{1 \mathrm{~B}}$ receptors inhibit transmitter release from nerve terminals (Hoyer and Middlemiss 1989; Martin and Humphrey 1994) and inhibit neuronal firing as somato-dendritic autoreceptors, respectively.

A common polymorphism at the human $5-\mathrm{HT}_{1 \mathrm{~B}}$ receptor locus (G861C) has been identified (Sidenberg et al. 1993; Lappalainen et al. 1995). An uncommon molecular variant with the substitution of a cysteine for a phenylalanine residue (F124C) has also been detected in the human 5- $\mathrm{HT}_{1 \mathrm{~B}}$ receptor gene (Nöthen et al. 1994).

In genomic DNA samples from 178 unrelated subjects, two polymorphisms of the $5-\mathrm{HT}_{1 \mathrm{~B}}$ receptor gene were identified in our laboratory (Huang et al. 1999). One is at nucleotide 861 ((Lappalainen et al. 1995). The other we have identified as a new polymorphism at nucleotide 129 of the coding region. This polymorphism was in absolute linkage disequilibrium with the polymorphism at nucleotide 861, meaning they always occur together. Across our entire study population, we found similar allelic frequencies ( 83 and $17 \%$ ) to those reported by Lappalainen (72 and $28 \%$ ). These two polymorphic sites are silent and do not change primary amino acid structure composition of the receptor.

We found no association of suicide, major depression, alcoholism, or a history of pathological aggression, with $5-\mathrm{HT}_{1 \mathrm{~B}}$ genotypes or allelic frequency for the two polymorphisms in a post-mortem study of $5-\mathrm{HT}_{1 \mathrm{~B}}$ binding (Huang et al. 1999). However, our study population was small and could have missed an uncommon association. Lappalainen and colleagues (Lappalainen et al. 1998) reported an association of alcoholism with the G861C locus. Alcoholics had a higher 861C allele frequency. In a separate group of Southwestern Native Americans, a condition described as antisocial alcoholism (implies a combination of aggressive traits and alcoholism) was also linked to G861C (Lappalainen et al. 1998). Our post-mortem sample included only 64 alcoholics, and we have now conducted further study of this possible association in a larger sample in vivo and found evidence of an association of alcoholism to the 861C allele.

We also found no difference in $5-\mathrm{HT}_{1 \mathrm{~B}}$ binding parameters in our post-mortem study between suicide, major depression, or individuals with pathological ag- 
gression and nonsuicides. Arranz and colleagues (Arranz et al. 1994) also found no difference in $B_{\max }$ and $K_{D}$ between the suicide and nonsuicide groups for the $5-\mathrm{HT}_{1 \mathrm{~B}}$ receptor in post-mortem frontal cortex samples. However, they found a significant decrease in the number of $5-\mathrm{HT}_{1 \mathrm{~B}}$ binding sites and in the $\mathrm{K}_{\mathrm{D}}$ in nondepressed suicides. We found the presence or absence of major depression made no difference to the results. Lowther and colleagues (Lowther et al. 1997) reported that there were significantly more $5-\mathrm{HT}_{1 \mathrm{~B}}$ receptor binding sites in globus pallidus but not in the frontal or parietal cortices from the antidepressant-free suicides who died by violent means. Thus, further study of the globus pallidus of suicides would be of interest. The absence of altered binding in prefrontal cortex in their study is in agreement with our results.

The 5- $\mathrm{HT}_{1 \mathrm{~B}}$ receptor seems to play a role in the modulation of aggressive behavior and alcohol or cocaine consumption in animal models (Saudou et al. 1994). We found no group differences in $5-\mathrm{HT}_{1 \mathrm{~B}}$ binding kinetics in association with alcoholism or pathological aggression. However, we did find a decrease in $5-\mathrm{HT}_{1 \mathrm{~B}}$ binding in the alcoholic group when using a matched pairs design (Arango et al. 1995b). Further such studies are needed in larger samples of pathologically aggressive patients as well as alcoholics.

\section{THE TRYPTOPHAN HYDROXYLASE GENE}

There are now seven positive candidate gene studies showing an association between a polymorphism of the tryptophan hydroxylase (TPH) gene and suicidal behavior and one positive linkage study. Linkage studies require knowledge of the relationship between subjects and usually involve members of the same family, such as an extended pedigree or pairs of siblings or parents and children. Because association studies involve unrelated larger populations, the results are often less reliable and subject to more confounds, such as differences in the frequency of the polymorphism in different populations, independent of disease. The associations with suicidal behavior are in opposite directions for impulsive criminal alcoholic attempters as compared to depressed attempters. Nielsen and colleagues (Nielsen et al. 1994) first reported an association between a polymorphism in the tryptophan hydroxylase (TPH) gene in intron 7, A779C, and suicidal behavior. Among a sample of 56 impulsive, alcoholic offenders, the L allele (equivalent to the $C$ allele) was associated with lower CSF 5-HIAA and a higher rate of attempted suicide ( 0.68 vs. $0.46, p<.02)$. These results were replicated and extended by Nielsen and colleagues (Nielsen et al. 1998), in a sample of 804 Finnish alcoholic offenders, controls, and their relatives. In an association study, the $\mathrm{L}$ allele was shown to be more common in the impul- sive offenders who attempted suicide (LL 72\%, UL, $59 \%$, and UU $31 \%$ ). This finding was even more striking if restricted to serious suicide attempts. In the nonimpulsive group, a significant association between suicidal behavior and TPH alleles was weaker, similar to that reported below by Mann and colleagues (Mann et al. 1997).

We (Mann et al. 1997) examined the prevalence of the same polymorphism in 29 depressed attempters and 22 depressed nonattempters. The rarer $U$ allele was found in higher frequency (41 vs. $20 \%$ ) in attempters, compared to nonattempters with major depression, and a dose response relationship between odds of suicide attempt and the U allele was found. Buresi and colleagues (Buresi et al. 1997) compared the prevalence of the A218C TPH polymorphism in 236 suicide attempters and 161 controls. The A218C polymorphism is in tight disequilibrium with the above noted A779C polymorphism, meaning they usually coexist in the same subject. The rarer A allele was more common among the suicide attempters ( 46.4 vs. $35.7 \%, p=.003$ ). The frequency of the A allele was even greater in those with serious ("violent") suicide attempts. These results were recently replicated in a Swedish sample (44.5 vs. $37 \%$ in controls) (Persson 1999), and are similar to those reported by Mann and colleagues (Mann et al. 1997).

Abbar and colleagues (Abbar et al. 1995) failed to find an association between an unspecified polymorphism of the TPH gene and suicide attempt. It is unclear if this polymorphism is in linkage disequilibrium with the above noted A218C and A779C polymorphisms. However, more recently, this group also found an association between the A218C TPH polymorphism and suicide attempt in a clinical sample.

The U allele of the A218C polymorphism of the TPH gene is associated with aggressive behavior in community volunteers and to a blunted prolactin response to the serotonin-releasing agent fenfluramine (Manuck et al. 1999). The $U$ allele is also associated with low CSF 5-HIAA (Jönsson et al. 1997). Thus, two different indices of serotonergic function indicate lower activity to be associated with the $U$ allele, the same allele associated with suicidal behavior in most studies. Lower serotonergic function could be a consequence of lower tryptophan hydroxylase activity resulting in less serotonin being synthesized. The intronic polymorphism may affect transcription rates or may be in linkage disequilibrium with another polymorphism of functional importance in the gene or its promoter region that, in turn, results in altered or reduced enzyme activity.

\section{SEROTONIN TRANSPORTER GENE}

Fewer platelet serotonin transporter sites and reduced platelet serotonin uptake have been reported in major 
depression (Malone and Mann 1993; Owens and Nemeroff 1994). Functional imaging and post-mortem brain studies conducted in depressed patients suggest that there may also be less 5-HTT binding in the brain (Perry et al. 1983; Arango et al. 1995a; Malison et al. 1998). Platelet 5-HTT binding seems to be unrelated to levels of brain 5-HTT binding (Owens and Nemeroff 1994; Malison et al. 1998). Thus, direct studies of the brain are necessary to determine the state of 5-HTT binding in major depression.

The serotonin transporter (5-HTT) binding site is found on serotonin nerve terminals and platelets (Langer et al. 1980; Laruelle et al. 1988), and as such it is regarded as an index of serotonin nerve terminal number or integrity (Paul et al. 1984; Laruelle et al. 1988; Arango and Mann 1992; Soucy et al. 1994). The human 5-HTT gene is located on chromosome 17q11.1-q12. A 44 base pair deletion/insertion polymorphism (5-HTTLPR) is present in the $5^{\prime}$ flanking regulatory region that results in differential expression of 5-HTT and $\mathrm{V}_{\max }$ for serotonin reuptake in transformed lymphoblastoid cell lines (Lesch et al. 1996). In these cell lines (Lesch et al. 1996), the short form of the 5-HTTLPR locus is associated with $40 \%$ fewer binding sites in the homozygote (SS) and the heterozygote (SL), compared with the long form (LL). Therefore, the presence of fewer 5-HTT sites on the platelets of depressed patients, and fewer 5-HTT sites in the prefrontal cortex of suicide victims, may be attributable to an association of the short form of the 5-HTTLPR locus with major depression or suicide.

However, it seems there is no association of the 5-HTTLPR genotype with a mood disorder. There are 14 studies examining linkage or association between the 5-HTTLPR locus and mood disorders in a variety of unipolar and bipolar samples from several ethnic groups. Only 4/14 studies are positive, and one of the positive studies (Du et al. 1999) found an association between depressed suicides and the long form of the 5-HTTLPR polymorphism, which is the opposite of the hypothesized relationship. Aggression, impulsivity, alcoholism, and substance abuse all carry an elevated risk of suicide and are also associated with serotonergic abnormalities (Whitaker-Azmitia and Peroutka 1990; Mann et al. 1999). Unfortunately, the 5-HTTLPR genotype is not clearly associated with alcoholism (Gelernter et al. 1997; Sander et al. 1997; Schuckit et al. 1999), or impulsive traits (Lesch et al. 1996; Ball et al. 1997; Ebstein et al. 1997).

We have replicated our previous report of lower 5-HTT binding localized to the ventral prefrontal cortex of suicide victims (Arango et al. 1995a). Most, but not all, studies of the serotonin transporter binding site in the brain of suicide victims (Stanley et al. 1982; Crow et al. 1984; Paul et al. 1984; Arató et al. 1987; Lawrence et al. 1990a, 1990b; Arató et al. 1991; Hrdina et al. 1993; Laruelle et al. 1993; Arango et al. 1995a; Mann et al. 1996; Du et al. 1999) report a reduction in 5-HTT bind- ing, although one found an increase (Meyerson et al. 1982) and four found no change in the prefrontal cortex (Owen et al. 1986; Gross-Isseroff et al. 1989; Arora and Meltzer 1989, 1991). One of the latter studies (GrossIsseroff et al. 1989) found increases and decreases in binding in an autoradiographic study of a variety of brain regions. The regionally restricted reduction in 5-HTT binding in suicide may partly explain the inconsistencies in the literature, because negative findings regarding 5-HTT binding and suicide may be a consequence of looking at the "wrong" brain region.

A limitation of most previous studies is the lack of information as to which cases of suicide or nonsuicides had a history of major depression. If there is a more widespread reduction in 5-HTT binding in major depression, that would mean that the choice of brain region would be less critical in studies that included a preponderance of cases with major depression. Of course, studies that included suicide victims who also had major depression could not distinguish effects of the two disorders separately.

Alterations in 5-HTT binding specifically related to suicide risk, seem to be concentrated in the ventral prefrontal cortex (PFC) (Arango et al. 1995a). This area plays a role in mediating inhibition or restraint. Acquired injuries of the ventral PFC are associated with disinhibition and an increase in impulsive behaviors including aggression and suicide attempts (Damasio et al. 1994; Shallice and Burgess 1996). Hence, we hypothesized that reduced serotonergic input into ventral prefrontal cortex, or lesions of the ventral prefrontal cortex, may underlie an impairment of behavioral inhibition or restraint, and an increased propensity for suicidal acts in patients who feel depressed or hopeless.

Increased corticosteroid secretion is associated with more severe depression (Sachar et al. 1970; Carroll et al. 1976; Brown et al. 1987), but preliminary animal studies do not suggest an effect on 5-HTT gene expression or binding (Kuroda et al. 1994). Thus, the cause of less 5-HTT binding in major depression remains unknown. There is less binding of ${ }^{123}$ I-beta-CIT in the midbrain of depressed patients using SPECT imaging (Malison et al. 1998). Studies of platelet serotonin transporter binding generally report fewer 5-HTT sites (Owens and Nemeroff 1994), suggesting a systemic reduction in 5-HTT sites in major depression. If so, that would also be consistent with a yet to be identified genetic cause or a systemic effect on gene expression.

\section{5-HT ${ }_{2 \mathrm{~A}}$ RECEPTOR AND GENE IN SUICIDAL BEHAVIOR}

Many, but not all, studies have found an increase in prefrontal cortical 5- $\mathrm{HT}_{2 \mathrm{~A}}$ receptor binding in the brain of suicide victims (see Arango et al. 1997 for a review). 
Moreover, platelet 5- $\mathrm{HT}_{2 \mathrm{~A}}$ receptor binding also seems to be increased in suicidal patients (Pandey 1997). This possible systemic effect raises the possibility of a genetic mechanism. A polymorphism has been reported at position $102(102 \mathrm{~T} / \mathrm{C})$ in the $5-\mathrm{HT}_{2 \mathrm{~A}}$ receptor gene (Zhang et al. 1997). Although $4 / 17$ studies found an association of the CC genotype or the $C$ allele with schizophrenia, there are few studies involving mood disorders (two negative results in bipolar disorder, one report of an association of the $C$ allele with major depression (Du et al. 2000), and one report of an association of the $\mathrm{T}$ allele with unipolar depression). Zhang and colleagues (Zhang et al. 1997) found a weak association of the TT genotype with suicide attempts in patients with mood disorders. Turecki and colleagues (Turecki et al. 1999), in a subsequent study of suicide victims, found no association with the same allele. Moreover, they also reported greater $5-\mathrm{HT}_{2 \mathrm{~A}}$ binding in the PFC of suicide victims and that the T allele was associated with higher $5-\mathrm{HT}_{2 \mathrm{~A}}$ binding. The increase in $5-\mathrm{HT}_{2 \mathrm{~A}}$ binding in the suicide victims seemed to be independent of this locus. Inconsistent with these two studies, Du and colleagues (Du et al. 2000) reported more suicidal ideation in association with the CC genotype. More work in this area would be of interest. Because there seem to be more $5-\mathrm{HT}_{2 \mathrm{~A}}$ receptors in suicide, functional polymorphisms involving the promoter region that affect gene expression may explain this finding. There are also suggestions that signal transduction via the $5-\mathrm{HT}_{2 \mathrm{~A}}$ receptor may be impaired in suicide attempters (Mann et al. 1992) and perhaps these protein variants are attributable to alternative splicing or in the case of the related $5-\mathrm{HT}_{2 \mathrm{C}}$ receptor, RNA editing, alter coupling efficiency to second messenger transducers.

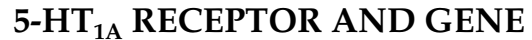

Although membrane binding studies have generated conflicting results, autoradiographic studies of $5-\mathrm{HT}_{1 \mathrm{~A}}$ binding in suicide victims reported increased binding (see Arango et al. 1997 for a review). Moreover, one group reports that, as with the reduction in 5-HTT binding, the increase in $5-\mathrm{HT}_{1 \mathrm{~A}}$ binding is localized to the orbital PFC. Both increased and decreased binding have been reported to the $5-\mathrm{HT}_{1 \mathrm{~A}}$ autoreceptor in the raphe nucleus of suicide victims (Kassir et al. 1998; Stockmeier et al. 1998). A role for the $5-\mathrm{HT}_{1 \mathrm{~A}}$ receptor in anxiety is suggested by inferences of increased anxiety in the $5-\mathrm{HT}_{1 \mathrm{~A}}$ knockout mouse model (Ramboz et al. 1998) and the anxiolytic effect of $5-\mathrm{HT}_{1 \mathrm{~A}}$ agonists.

A common polymorphism (C-1018G) has been reported in the human $5-\mathrm{HT}_{1 \mathrm{~A}}$ gene $(\mathrm{Wu}$ and Comings 1999). Nakhai and Nielsen (Nakhai et al. 1995) reported two amino acid substitutions in the $5-\mathrm{HT}_{1 \mathrm{~A}}$ receptor (glycine22serine; isoleucine 28valine). Xie and Deng
(Xie et al. 1995) report an amino acid substitution and insertion at positions $454-459$ but no association with mood disorders. Studies of these polymorphisms in suicide, mood disorders, and anxiety disorders are awaited. What we seek are relevant functional polymorphisms that alter gene expression, receptor affinity, or receptor coupling to second messenger components.

\section{MONOAMINE OXIDASE A GENE}

Monoamine oxidase (MAO) A preferentially deaminates norepinephrine and serotonin. Deletion of the $\mathrm{x}$-chromosomal MAOA gene in mice results in a more aggressive phenotype (Cases et al. 1995). A chain termination mutation in the eighth axon in a Dutch kindred (Brunner et al. 1993a, 1993b) is linked to mental retardation and pathological aggression, including arson, in males only. A variable repeat (VNTR) is found in the $5^{\prime}$ flanking promoter region and results in differences in gene expression in vitro ((Sabol et al. 1998). Alleles 1 and 4 showed less transcriptional activity than alleles 2 and 3 in MAOA promoter constructs (Sabol et al. 1998). We have found that in comparison to the $2 / 3$ allele group (males), the $1 / 4$ allele group in males was less aggressive and impulsive and had greater serotonergic activity as measured by the prolactin response to fenfluramine ((Manuck et al. in press). A dinucleotide repeat in intron 2 (MAOA-CA $\mathrm{n}_{\mathrm{n}}$ ), in linkage disequilibrium with the uVNTR MAOA polymorphism, was not associated with behavior or serotonergic function (Manuck et al. in press). Further study of the relationship between possible less MAOA gene expression and serotonergic activity in humans is needed. The absence of MAOA and increased aggression is understandable as a consequence of more norepinephrine or potential developmental abnormalities and not attributable to more serotonin.

\section{CONCLUSIONS}

Many significant abnormalities have been found in the serotonergic system in suicide attempters and completers. Studies of candidate genes are in an early phase, but promising results are emerging that suggest that genetic factors influencing suicide risk may operate, at least in part, through the serotonergic system. Future approaches should examine the relationship of genetic variants to intermediate phenotypes such as impulsivity, psychomotor change, components of altered sleep architecture, substance abuse, pathological aggression, and biological abnormalities, including specific gene products. Terwilliger has advocated this approach, because the relationship of intermediate phenotypes to causal or vulnerability genes is closer and easier to 
demonstrate than to complex syndromes or diseases (Terwilliger and Göring 2000). Post-mortem studies can examine gene expression as well as protein products. In vivo studies can quantify receptors and transmitter turnover or synthesis. These neurobiological indices offer a growing array of intermediate phenotypes.

\section{ACKNOWLEDGMENTS}

The work described in this paper was supported by PHS Grants MH46745, MH40695, MH40210, MH56390, MH56612, MH55123, AA09004, The Diane Goldberg Foundation, and The Audrey Wallace Otto Fund of the St. Louis Community Foundation.

\section{REFERENCES}

Abbar M, Courtet P, Amadéo S, Caer Y, Mallet J, BaldyMoulinier M, Castelnau D, Malafosse A (1995): Suicidal behaviors and the tryptophan hydroxylase gene. Arch Gen Psychiat 52:846-849

Arango V, Khait VD, Mann JJ (1995b): Binding to 5- $\mathrm{HT}_{1 \mathrm{D}}$ sites is reduced in prefrontal cortex of alcoholics. Soc Neurosci Abstr 21:1732

Arango V, Mann JJ (1992): Relevance of serotonergic postmortem studies to suicidal behavior. Int Rev Psychiat 4:131-140

Arango V, Underwood MD (1997): Serotonin chemistry in the brain of suicide victims. In Maris R, Silverman M, Canetto S (eds), Review of Suicidology, 1997, 1st ed. New York: Guilford Press, pp 237-250

Arango V, Underwood MD, Gubbi AV, Mann JJ (1995a): Localized alterations in pre- and postsynaptic serotonin binding sites in the ventrolateral prefrontal cortex of suicide victims. Brain Res 688:121-133

Arango V, Underwood MD, Mann JJ (1997): Postmortem findings in suicide victims: Implications for in vivo imaging studies. Ann NY Acad Sci 836:269-287

Arató M, Tekes K, Palkovits M, Demeter E, Falus A (1987): Serotonergic split brain and suicide. Psychiat Res 21:355-356

Arató M, Tekes K, Tóthfalusi L, Magyar K, Palkovits M, Frecska E, Falus A, MacCrimmon DJ (1991): Reversed hemispheric asymmetry of imipramine binding in suicide victims. Biol Psychiat 29:699-702

Arora RC, Meltzer HY (1989): ${ }^{3} \mathrm{H}$-imipramine binding in the frontal cortex of suicides. Psychiat Res 30:125-135

Arora RC, Meltzer HY (1991): Laterality and ${ }^{3} \mathrm{H}$-imipramine binding: Studies in the frontal cortex of normal controls and suicide victims. Biol Psychiat 29:1016-1022

Arranz B, Eriksson A, Mellerup E, Plenge P, Marcusson J (1994): Brain 5- $\mathrm{HT}_{1 \mathrm{~A}}, 5-\mathrm{HT}_{1 \mathrm{D}}$, and $5-\mathrm{HT}_{2}$ receptors in suicide victims. Biol Psychiat 35:457-463

Ashcroft GW, Blackburn IM, Eccleston D, Glen AIM, Harley W, Kinloch NE, Lonergan M, Murray LG, Pullar IA (1973b): Changes on recovery in the concentrations of tryptophan and the biogenic amine metabolites in the cerebrospinal fluid of patients with affective illness. Psychol Med 3:319-325

Ashcroft GW, Crawford TBB, Cundall RL, Davidson DL, Dobson J, Dow RC, Eccleston D, Loose RW, Pullar IA (1973a): 5-Hydroxytryptamine metabolites in affective illness: The effect of tryptophan administration. Psychol Med 3:326-332

Åsberg M, Bertilsson L, Martensson B, Scalia Tomba GP, Thorén P, Träskman-Bendz L (1984): CSF monoamine metabolites in melancholia. Acta Psychiat Scand 69: 201-219

Åsberg M, Eriksson B, Mårtensson B, Träskman-Bendz L, Wägner A (1986a): Therapeutic effects of serotonin uptake inhibitors in depression. J Clin Psychiat 47 4(Suppl):23-35

Åsberg M, Nordström P, Träskman-Bendz L (1986b): Cerebrospinal fluid studies in suicide. An overview. Ann NY Acad Sci 487:243-255

Ball D, Hill L, Freeman B, Eley TC, Strelau J, Riemann R, Spinath FM, Angleitner A, Plomin R (1997): The serotonin transporter gene and peer-rated neuroticism. NeuroReport 8:1301-1304

Ballenger JC, Goodwin FK, Major LF, Brown GL (1979): Alcohol and central serotonin metabolism in man. Arch Gen Psychiat 36:224-227

Barratt ES (1965): Factor analysis of some psychometric measures of impulsiveness and anxiety. Psycholog Repts 16:547-554

Bowers MB, Jr (1974): Lumbar CSF 5-hydroxyindoleacetic acid and homovanillic acid in affective syndromes. J Nerv Ment Dis 158:325-330

Brent DA, Bridge J, Johnson BA, Connolly J (1996): Suicidal behavior runs in families. A controlled family study of adolescent suicide victims. Arch Gen Psychiat 53:11451152

Brown RP, Stoll PM, Stokes PE, Frances A, Sweeney JA, Kocsis JH, Mann JJ (1987): Adrenocortical hyperactivity in depression: Effects of agitation, delusions, melancholia, and other illness variables. Psychiat Res 23:167-178

Brunner HG, Nelen M, Breakefied XO, Ropers HH, van Oost BA (1993a): Abnormal behavior associated with a point mutation in the structural gene for monoamine oxidase A. Science 262:578-580

Brunner HG, Nelen MR, van Zandvoort P, Abeling NGGM, van Gennip AH, Wolters EC, Kuiper MA, Ropers HH, van Oost BA (1993b): X-linked borderline mental retardation with prominent behavioral disturbance: Phenotype, genetic localization, and evidence for disturbed monoamine metabolism. Am J Human Genet 52:1032-1039

Buresi C, Courtet Ph, Leboyer M, Feingold J, Malafosse A (1997): Association between suicide attempt and the trytophane hydroxylase (TPH) gene. Am Soc Human Genetics: A270-A270

Carroll BJ, Curtis GC, Davies BM, Mendels J, Sugerman AA (1976): Urinary free cortisol excretion in depression. Psychol Med 6:43-50

Cases O, Seif I, Grimsby J, Gaspar P, Chen K, Pournin S, Müller U, Aguet M, Babinet C, Shih JC, De Maeyer E (1995): Aggressive behavior and altered amounts of brain serotonin and norepinephrine in mice lacking MAOA. Science 268:1763-1766 
Coccaro EF, Siever LJ, Klar HM, Maurer G, Cochrane K, Cooper TB, Mohs RC, Davis KL (1989): Serotonergic studies in patients with affective and personality disorders. Correlates with suicidal and impulsive aggressive behavior. Arch Gen Psychiat 46:587-599

Cowen PJ, McCance SL, Gelder MG, Grahame-Smith DG (1990): Effect of amitriptyline on endocrine responses to intravenous L-tryptophan. Psychiat Res 31:201-208

Crabbe JC, Phillips TJ, Feller DJ, Hen R, Wenger CD, Lessov CN, Schafer GL (1996): Elevated alcohol consumption in null mutant mice lacking $5-\mathrm{HT}_{1 \mathrm{~B}}$ serotonin receptors. Nature Genet 14:98-101

Crabbe JC, Wahlsten D, Dudek BC (1999): Genetics of mouse behavior: Interactions with laboratory environment. Science 284:1670-1672

Crow TJ, Cross AJ, Cooper SJ, Deakin JFW, Ferrier IN, Johnson JA, Joseph MH, Owen F, Poulter M, Lofthouse R, Corsellis JAN, Chambers DR, Blessed G, Perry EK, Perry RH, Tomlinson BE (1984): Neurotransmitter receptors and monoamine metabolites in the brains of patients with Alzheimer-type dementia and depression, and suicides. Neuropharmacology 23:1561-1569

Damasio H, Grabowski T, Frank R, Galaburda AM, Damasio AR (1994): The return of Phineas Gage: Clues about the brain from the skull of a famous patient. Science 264:1102-1105

Delgado PL, Charney DS, Price LH, Aghajanian GK, Landis H, Heniger GR (1990): Serotonin function and the mechanism of antidepressant action. Reversal of antidepressant-induced remission by rapid depletion of plasma tryptophan. Arch Gen Psychiat 47:411-418

Demchyshyn L, Sunahara RK, Miller K, Teitler M, Hoffman BJ, Kennedy JL, Seeman P, Van Tol HHM, Niznik HB (1992): A human serotonin 1D receptor variant (5HT1D $\beta$ ) encoded by an intronless gene on chromosome 6. Proc Natl Acad Sci USA 89:5522-5526

Du L, Bakish D, Lapierre YD, Ravindran AV, Hrdina PD (2000): Association of polymorphism of serotonin 2A receptor gene with suicidal ideation in major depressive disorder. Am J Med Genet 96:56-60

Du L, Faludi G, Palkovits M, Demeter E, Bakish D, Lapierre YD, Sótonyi P, Hrdina PD (1999): Frequency of long allele in serotonin transporter gene is increased in depressed suicide victims. Biol Psychiat 46:196-201

Ebstein RP, Gritsenko I, Nemanov L, Frisch A, Osher Y, Belmaker RH (1997): No association between the serotonin transporter gene regulatory region polymorphism and the Tridimensional Personality Questionnaire (TPQ) temperament of harm avoidance. Molec Psychiat 2: 224-226

Egeland JA, Sussex JN (1985): Suicide and family loading for affective disorders. J Am Med Assoc 254(7):915-918

Flory JD, Mann JJ, Manuck SB, Muldoon MF (1998): Recovery from major depression is not associated with normalization of serotonergic function. Biol Psychiat 43:320-326

Fulwiler C, Grossman H, Forbes C, Ruthazer R (1997): Early onset substance abuse and community violence by outpatients with chronic mental illness. Psychiat Servcs 48:1181-1185

Gelernter J, Kranzler H, Cubells JF (1997): Serotonin trans- porter protein (SLC6A4) allele and haplotype frequencies and linkage disequilibria in African- and EuropeanAmerican and Japanese populations and in alcoholdependent subjects. Hum Genet 101:243-246

Gerner RH, Fairbanks L, Anderson GM, Young JG, Scheinin M, Linnoila M, Hare TA, Shaywitz BA, Cohen DJ (1984): CSF Neurochemistry in depressed, manic, and schizophrenic patients compared with that of normal controls. Am J Psychiat 141(12):1533-1540

Gershon ES (1990): Genetics. In Goodwin FK, Jamison KR (eds), Manic-Depressive Illness. New York, Oxford: Oxford University Press, pp 373-401

Gershon ES, Berrettini WH, Nurnberger JI, Jr, Goldin LR (1989): Genetic studies of affective illness. In Mann JJ (ed), Models of Depressive Disorder. New York; Plenum, pp 109-142

Goodwin FK, Post RM (1977): Catecholamine metabolite studies in the affective disorders: Issues of specificity and significance. In Usdin E (ed), Neuroregulators and Psychiatric Disorders. New York: Oxford University Press, pp 135-145

Gross-Isseroff R, Israeli M, Biegon A (1989): Autoradiographic analysis of tritiated imipramine binding in the human brain postmortem: Effects of suicide. Arch Gen Psychiat 46:237-241

Hamblin MW, Metcalf MA (1991): Primary structure and functional characterization of a human $5-\mathrm{HT}_{1 \mathrm{D}}$-type serotonin receptor. Mol Pharmacol 40:143-148

Heninger GR, Charney DS, Sternberg DE (1984): Serotonergic function in depression. Prolactin response to intravenous tryptophan in depressed patients and healthy subjects. Arch Gen Psychiat 41:398-402

Higley JD, King ST, Hasert MF, Champoux M, Suomi SJ, Linnoila M (1996): Stability of interindividual differences in serotonin function and its relationship to severe aggression and competent social behavior in rhesus macaque females. Neuropsychopharmacology 14:67-76

Higley JD, Mehlman PT, Taub DM, Higley SB, Suomi SJ, Linnoila M, Vickers JH (1992): Cerebrospinal fluid monoamine and adrenal correlates of aggression in free-ranging rhesus monkeys. Arch Gen Psychiat 49:436-441

Higley JD, Thompson WW, Champoux M, Goldman D, Hasert MF, Kraemer GW, Scanlan JM, Suomi SJ, Linnoila M (1993): Paternal and maternal genetic and environmental contributions to cerebrospinal fluid monoamine metabolites in rhesus monkeys (Macaca mulatta). Arch Gen Psychiat 50:615-623

Hoyer D, Middlemiss DN (1989): Species differences in the pharmacology of terminal 5-HT autoreceptors in mammalian brain. Trends Pharmacol Sci 10:130-132

Hrdina PD, Demeter E, Vu TB, Sótónyi P, Palkovits M (1993): 5-HT uptake sites and 5- $\mathrm{HT}_{2}$ receptors in brain of antidepressant-free suicide victims/depressives: Increase in $5-\mathrm{HT}_{2}$ sites in cortex and amygdala. Brain Res 614:37-44

Huang Y, Grailhe R, Arango V, Hen R, Mann JJ (1999): Relationship of psychopathology to the human serotonin ${ }_{1 \mathrm{~B}}$ genotype and receptor binding kinetics in postmortem brain tissue. Neuropsychopharmacology 21:238-246 
Ishikawa K, Shibanoki S, Kubo T, Kogure M, Imamura Y, Osawa N, Ohmura M, Mikoshiba K (1989): Functional difference in monoamine transmitters in the behaviorally abnormal mouse mutant (wriggle mouse sagami). Neurosci Lett 103:343-348

Jönsson EG, Goldman D, Spurlock G, Gustavsson JP, Nielsen DA, Linnoila M, Owen MJ, Sedvall GC (1997): Tryptophan hydroxylase and catechol-O-methyltransferase gene polymorphisms: Relationships to monoamine metabolite concentrations in CSF of healthy volunteers. Eur Arch Psychiat Clin Neurosci 247:297-302

Kassir SA, Underwood MD, Bakalian MJ, Mann JJ, Arango V (1998): $5-\mathrm{HT}_{1 \mathrm{~A}}$ binding in dorsal and median raphe nuclei of suicide victims. Soc Neurosci Abstr 24:12741274

Koslow SH, Maas JW, Bowden CL, David JM, Hanin I, Javaid J (1983): CSF and urinary biogenic amines and metabolism in depression and mania. A controlled univariate analysis. Arch Gen Psychiat 40:999-1010

Kuroda Y, Watanabe Y, Albeck DS, Hastings NB, McEwen BS (1994): Effects of adrenalectomy and Type I or Type II glucocorticoid receptor activation on $5-\mathrm{HT}_{1 \mathrm{~A}}$ and 5- $\mathrm{HT}_{2}$ receptor binding and 5-HT transporter mRNA expression in rat brain. Brain Res 648:157-161

Langer SZ, Moret C, Raisman R, Dubocovich ML, Briley M (1980): High-affinity $\left[{ }^{3} \mathrm{H}\right]$ imipramine binding in rat hypothalamus: Association with uptake of serotonin but not of norepinephrine. Science 210:1133-1135

Lappalainen J, Dean M, Charbonneau L, Virkkunen M, Linnoila M, Goldman D (1995): Mapping of the serotonin $5-\mathrm{HT}_{1 \mathrm{D} \beta}$ autoreceptor gene on chromosome 6 and direct analysis for sequence variants. Am J Med Genet 60: 157-161

Lappalainen J, Long JC, Eggert M, Ozaki N, Robin RW, Brown GL, Naukkarinen H, Virkkunen M, Linnoila M, Goldman D (1998): Linkage of antisocial alcoholism to the serotonin 5-HT1B receptor gene in two populations. Arch Gen Psychiat 55:989-994

Laruelle M, Abi-Dargham A, Casanova MF, Toti R, Weinberger DR, Kleinman JE (1993): Selective abnormalities of prefrontal serotonergic receptors in schizophrenia: A postmortem study. Arch Gen Psychiat 50:810-818

Laruelle M, Vanisberg MA, Maloteaux JM (1988): Regional and subcellular localization in human brain of $\left[{ }^{3} \mathrm{H}\right]$ paroxetine binding, a marker of serotonin-uptake sites. Biol Psychiat 24:299-309

Lawrence KM, De Paermentier F, Cheetham SC, Crompton MR, Katona CLE, Horton RW (1990b): Brain 5-HT uptake sites, labeled with $\left[{ }^{3} \mathrm{H}\right]$ paroxetine, in antidepressant-free depressed suicides. Brain Res 526:17-22

Lawrence KM, De Paermentier F, Cheetham SC, Crompton MR, Katona CLE, Horton RW (1990a): Symmetrical hemispheric distribution of ${ }^{3} \mathrm{H}$-paroxetine binding sites in post-mortem human brain from controls and suicides. Biol Psychiat 28:544-546

Lesch K-P, Bengel D, Heils A, Sabol SZ, Greenberg BD, Petri S, Benjamin J, Müller CR, Hamer DH, Murphy DL (1996): Association of anxiety-related traits with a polymorphism in the serotonin transporter gene regulatory region. Science 274:1527-1531

Levy FO, Gudermann T, Perez-Reyes E, Birnbaumer M, Kaumann AJ, Birnbaumer L (1992): Molecular cloning of a human serotonin receptor (S12) with a pharmacological profile resembling that of the $5-\mathrm{HT}_{1 \mathrm{D}}$ subtype. J Biol Chem 267:7553-7562

Lowther S, Katona CLE, Crompton MR, Horton RW (1997): $5 \mathrm{HT}_{1 \mathrm{D}}$ and $5-\mathrm{HT}_{1 \mathrm{E} / 1 \mathrm{~F}}$ binding sites in depressed suicides: Increased $5-\mathrm{HT}_{1 \mathrm{D}}$ binding in globus pallidus but not cortex. Molec Psychiat 2:314-321

Malison RT, Price LH, Berman R, Van Dyck CH, Pelton GH, Carpenter L, Sanacora G, Owens MJ, Nemeroff CB, Rajeevan N, Baldwin RM, Seibyl JP, Innis RB, Charney DS (1998): Reduced brain serotonin transporter availability in major depression as measured by [ $\left.{ }^{123} \mathrm{I}\right]-2 \beta$-carbomethoxy-3 $\beta$-(4-iodophenyl)tropane and single photon emission computer tomography. Biol Psychiat 44: 1090-1098

Malone KM, Mann JJ (1993): Serotonin and major depression. In Mann JJ, Kupfer DJ (eds), Biology of Depressive Disorders, vol. 3, part A: A System Perspective. New York: Plenum Press, pp 29-49

Mann JJ (1995): Violence and aggression. In Bloom FE, Kupfer DJ (eds), Psychopharmacology: The Fourth Generation of Progress. New York: Raven Press, pp 19191928

Mann JJ (1998): The neurobiology of suicide. Nature Med 4:25-30

Mann JJ, Arango V, Marzuk PM, Theccanat S, Reis DJ (1989): Evidence for the 5-HT hypothesis of suicide: A review of post-mortem studies. Br J Psychiat 155 (Suppl 8):7-14

Mann JJ, Henteleff RA, Lagattuta TF, Perper JA, Li S, Arango V (1996): Lower ${ }^{3} \mathrm{H}$-paroxetine binding in cerebral cortex of suicide victims is partly due to fewer high-affinity, nontransporter sites. J Neural Transm 103:13371350

Mann JJ, Malone KM, Nielsen DA, Goldman D, Erdos J, Gelernter J (1997): Possible association of a polymorphism of the tryptophan hydroxylase gene with suicidal behavior in depressed patients. Am J Psychiat 154:1451-1453

Mann JJ, McBride PA, Brown RP, Linnoila M, Leon AC, DeMeo MD, Mieczkowski TA, Myers JE, Stanley M (1992): Relationship between central and peripheral serotonin indexes in depressed and suicidal psychiatric inpatients. Arch Gen Psychiat 49(6):442-446

Mann JJ, Stanley M (1986): Psychobiology of Suicidal Behavior. New York: The New York Academy of Sciences

Mann JJ, Waternaux C, Haas GL, Malone KM (1999): Towards a clinical model of suicidal behavior in psychiatric patients. Am J Psychiat 156:181-189

Manuck SB, Flory JD, Ferrell RE, Dent KM, Mann JJ, Muldoon MF (1999): Aggression and anger-related traits associated with a polymorphism of the tryptophan hydroxylase gene. Biol Psychiat 45:603-614

Manuck SB, Flory JD, Ferrell RE, Mann JJ, Muldoon MF (in press): A regulatory polymorphism of the monoamine oxidase-A gene maybe associated with variability in aggression, impulsivity, and central nervous system serotonergic responsivity. Psychiat Res

Martin GR, Humphrey PPA (1994): Receptors for 5-hydroxytryptamine: Current perspectives on classification and nomenclature. Neuropharmacology 33:261-273

Mendels J, Frazer A, Fitzgerald RG, Ramsey TA, Stokes JW 
(1972): Biogenic amine metabolites in cerebrospinal fluid of depressed and manic patients. Science 175: 1380-1382

Meyerson LR, Wennogle LP, Abel MS, Coupet J, Lippa AS, Rauh CE, Beer B (1982): Human brain receptor alterations in suicide victims. Pharmacol Biochem Behav 17:159-163

Molina V, Ciesielski L, Gobaille S, Isel F, Mandel P (1987): Inhibition of mouse killing behavior by serotoninmimetic drugs: Effects of partial alterations of serotonin neurotransmission. Pharmacol Biochem Behav 27: 123-131

Nakhai B, Nielsen DA, Linnoila M, Goldman D (1995): Two naturally occurring amino acid substitutions in the human 5- $\mathrm{HT}_{1 \mathrm{~A}}$ receptor: Glycine 22 to serine 22 and isoleucine 28 to valine 28. Biochem Biophys Res Commun 210:530-536

Nielsen DA, Goldman D, Virkkunen M, Tokola R, Rawlings R, Linnoila M (1994): Suicidality and 5-hydroxyindoleacetic acid concentration associated with a tryptophan hydroxylase polymorphism. Arch Gen Psychiat 51:34-38

Nielsen DA, Virkkunen M, Lappalainen J, Eggert M, Brown GL, Long JC, Goldman D, Linnoila M (1998): A tryptophan hydroxylase gene marker for suicidality and alcoholism. Arch Gen Psychiat 55:593-602

Nordström P, Samuelsson M, Åsberg M, Träskman-Bendz L, Aberg-Wistedt A, Nordin C, Bertilsson L (1994): CSF 5-HIAA predicts suicide risk after attempted suicide. Suicide Life Threat Behav 24:1-9

Nöthen MM, Erdmann J, Shimron-Abarbanell D, Propping P (1994): Identification of genetic variation in the human serotonin 1D $\beta$ receptor gene. Biochem Biophys Res Commun 205:1194-1200

O'Keane V, Dinan TG (1991): Prolactin and cortisol responses to $d$-fenfluramine in major depression: Evidence for diminished responsivity of central serotonergic function. Am J Psychiat 148:1009-1015

Owen F, Chambers DR, Cooper SJ, Crow TJ, Johnson JA, Lofthouse R, Poulter M (1986): Serotonergic mechanisms in brains of suicide victims. Brain Res 362:185-188

Owens MJ, Nemeroff CB (1994): Role of serotonin in the pathophysiology of depression: Focus on the serotonin transporter. Clin Chem 40:288-295

Pandey GN (1997): Altered serotonin function in suicide. Evidence from platelet and neuroendocrine studies. Ann NY Acad Sci 836:182-183

Paul SM, Rehavi M, Skolnick P, Goodwin FK (1984): Highaffinity binding of antidepressants to a biogenic amine transport site in human brain and platelet; studies in depression. In Post RM, Bellinger CJ (eds), Neurobiology of Mood Disorders. Baltimore: Williams \& Wilkins, pp 846-853

Perry EK, Marshall EF, Blessed G, Tomlinson BE, Perry RH (1983): Decreased imipramine binding in the brains of patients with depressive illness. Br J Psychiat 142:188192

Persson M-L (1999): Suicide Attempt and Genes. Psychiatric and Genetic Characteristics of Suicide Attempters. Stockholm; Kongl Karolinska Medico Chirurgiska Institutet
Post RM, Goodwin FK (1974): Brain research mechanisms and symptom formation. Estimation of brain amine metabolism in affective illness: Cerebrospinal fluid studies utilizing probenecid. Psychother Psychosom 23:142-158

Price LH, Charney DS, Delgado PL, Heninger GR (1991): Serotonin function and depression: Neuroendocrine and mood responses to intravenous L-tryptophan in depressed patients and healthy comparison subjects. Am J Psychiat 148:1518-1525

Ramboz S, Oosting R, Amara DA, Kung HF, Blier P, Mendelsohn M, Mann JJ, Brunner D, Hen R (1998): Serotonin receptor 1A knockout: An animal model of anxietyrelated disorder. Proc Natl Acad Sci USA 95:14476-14481

Ramboz S, Saudou F, Amara DA, Belzung C, Segu L, Misslin R, Buhot M-C, Hen R (1996): 5- HT $_{1 B}$ receptor knock outBehavioral consequences. Behav Brain Res 73:305-312

Redmond DE, Katz MM, Maas JW, Swann A, Casper R, Davis JM (1986): Cerebrospinal fluid amine metabolites. Arch Gen Psychiat 43:938-947

Rocha BA, Scearce-Levie K, Lucas JJ, Hiroi N, Castanon N, Crabbe JC, Nestler EJ, Hen R (1998): Increased vulnerability to cocaine in mice lacking the serotonin-1B receptor. Nature 393:176-178

Roy A (1986): Genetics of suicide. Ann NY Acad Sci 487:97-105

Roy A (1993): Genetic and biologic risk factors for suicide in depressive disorders. Psychiat Quart 64:345-358

Roy A, De Jong J, Linnoila M (1989): Cerebrospinal fluid monoamine metabolites and suicidal behavior in depressed patients. A 5-year follow-up study. Arch Gen Psychiat 46:609-612

Roy A, Pickar D, Linnoila M, Doran AR, Ninan P, Paul SM (1985): Cerebrospinal fluid monoamine and monoamine metabolite concentrations in melancholia. Psychiat Res 15:281-292

Roy A, Segal NL, Centerwall BS, Robinette CD (1991): Suicide in twins. Arch Gen Psychiat 48:29-32

Roy A, Segal NL, Sarchiapone M (1995): Attempted suicide among living co-twins of twin suicide victims. Am J Psychiat 152:1075-1076

Sabol SZ, Hu S, Hamer D (1998): A functional polymorphism in the monoamine oxidase A gene promoter. Hum Genet 103:273-279

Sachar EJ, Hellman L, Fukushima DK, Gallagher TF (1970): Cortisol production in depressive illness. Arch Gen Psychiat 23:289-298

Sander T, Harms H, Lesch K-P, Dufeu P, Kuhn S, Hoehe M, Rommelspacher H, Schmidt LG (1997): Association analysis of a regulatory variation of the serotonin transporter gene with severe alcohol dependence. Alcohol Clin Exp Res 21:1356-1359

Saudou F, Amara DA, Dierich A, Lemeur M, Ramboz S, Segu L, Buhot M-C, Hen R (1994): Enhanced aggressive behavior in mice lacking $5-\mathrm{HT}_{1 \mathrm{~B}}$ receptor. Science 265:1875-1878

Schuckit MA, Li T-K, Cloninger CR, Deitrich RA (1985): Genetics of alcoholism. Alcohol Clin Exp Res 9:476-492

Schuckit MA, Mazzanti C, Smith TL, Ahmed U, Radel M, Iwata N, Goldman D (1999): Selective genotyping for the role of $5-\mathrm{HT}_{2 \mathrm{~A}}, 5-\mathrm{HT}_{2 \mathrm{C}}$, and $\mathrm{GABA}_{\alpha 6}$ receptors and 
the serotonin transporter in the level of response to alcohol: A pilot study. Biol Psychiat 45:647-651

Schulsinger F, Kety SS, Rosenthal D, Wender PH (1979): A family study of suicide. In Schou M, Stromgren E (eds), Origin, Prevention, and Treatment of Affective Disorders. New York: Academic Press, pp 277-287

Shallice T, Burgess P (1996): The domain of supervisory processes and temporal organization of behaviour. Phil Trans R Soc Lond 351:1405-1412

Shopsin B, Friedman E, Gershon S (1976): Parachlorophenylalanine reversal of tranylcypromine effects in depressed patients. Arch Gen Psychiat 33:811-819

Sidenberg DG, Bassett AS, Demchyshyn L, Niznik HB, Macciardi F, Kamble AB, Honer WG, Kenndey JL (1993): New polymorphism for the human serotonin 1D receptor variant $\left(5-\mathrm{HT}_{1 \mathrm{D} \beta}\right)$ not linked to schizophrenia in five Canadian pedigrees. Hum Hered 43:315-318

Siever LJ, Murphy DL, Slater S, de la Vega E, Lipper S (1984): Plasma prolactin changes following fenfluramine in depressed patients compared to controls: An evaluation of central serotonergic responsivity in depression. Life Sci 34:1029-1039

Sjöström R, Roos B-E (1972): 5-hydroxyindolacetic acid and homovanillic acid in cerebrospinal fluid in manicdepressive psychosis. Eur J Clin Pharmacol 4:170-176

Soucy J-P, Lafaille F, Lemoine P, Mrini A, Descarries L (1994): Validation of the transporter ligand cyanoimipramine as a marker of serotonin innervation density in brain. J Nucl Med 35:1822-1830

Stanley M, Virgilio J, Gershon S (1982): Tritiated imipramine binding sites are decreased in the frontal cortex of suicides. Science 216:1337-1339

Statham DJ, Heath AC, Madden PAF, Bucholz KK, Biesrut L, Dinwiddie SH, Slutske WS, Dunne MP, Martin NG (1998): Suicidal behaviour: An epidemiological and genetic study. Psychol Med 28:839-855

Stockmeier CA, Shapiro LA, Dilley GE, Kolli TM, Friedman L, Rajkowska G (1998): Increase in serotonin-1A autoreceptors in the midbrain of suicide victims with major depression-Post-mortem evidence for decrease serotonin activity. J Neurosci 18:7394-7401

Stoff DM, Mann JJ (1997): The neurobiology of suicide. From the Bench to the Clinic. New York: The New York Academy of Sciences

Terwilliger JD, Göring HHH (2000): Gene mapping in the 20th and 21st centuries: Statistical methods, data analysis, and experimental design. Human Biol 72:63-132
Träskman-Bendz L, Alling C, Oreland L, Regnéll G, Vinge E, Öhman R (1992): Prediction of suicidal behavior from biologic tests. J Clin Psychopharmacol 12 Suppl:21S-26S

Turecki G, Brière $R$, Dewar $K$, Antonetti $T$, Lesage $A D$, Séguin M, Chawky N, Vanier C, Alda M, Joober R, Benkelfat C, Rouleau GA (1999): Prediction of level of serotonin $2 \mathrm{~A}$ receptor binding by serotonin receptor $2 \mathrm{~A}$ genetic variation in postmortem brain samples from subjects who did or did not commit suicide. Am J Psychiat 156:1456-1458

Upadhyaya AK, Pennell I, Cowen PJ, Deakin JFW (1991): Blunted growth hormone and prolactin responses to L-tryptophan in depression; A state-dependent abnormality. J Affect Disord 21:213-218

van Praag HM, de Haan S (1979): Central serotonin metabolism and frequency of depression. Psychiat Res 1:219-224

Vergnes M, Depaulis A, Boehrer A (1986): Parachlorophenylalanine-induced serotonin depletion increases offensive but not defensive aggression male rats. Physiol Behav 36:653-658

Virkkunen M, Rawlings R, Tokola R, Poland RE, Guidotti A, Nemeroff CB, Bissette G, Kalogeras K, Karonen S-L, Linnoila M (1994): CSF biochemistries, glucose metabolism, and diurnal activity rhythms in alcoholic, violent offenders, fire setters, and healthy volunteers. Arch Gen Psychiat 51:20-27

Weinshank RL, Zgombick JM, Macchi MJ, Branchek TA, Hartig PR (1992): Human serotonin 1D receptor is encoded by a subfamily of two distinct genes: $5-\mathrm{HT}_{1 \mathrm{D} \alpha}$ and 5-HT $\mathrm{T}_{1 \mathrm{D} \beta}$. Proc Natl Acad Sci USA 89:3630-3634

Weissman M, Fox K, Klerman GL (1973): Hostility and depression associated with suicide attempts. Am J Psychiat 130(4):450-455

Whitaker-Azmitia PM, Peroutka SJ (1990): The Neuropharmacology of Serotonin. New York: The New York Academy of Sciences

Wu S, Comings DE (1999): A common C-1018G polymorphism in the human $5-\mathrm{HT}_{1 \mathrm{~A}}$ receptor gene. Psychiat Genet 9:105-106

Xie D-W, Deng Z-L, Ishigaki T, Nakamura Y, Suzuki Y, Miyasato K, Ohara K (1995): The gene encoding the $5-\mathrm{HT}_{1 \mathrm{~A}}$ receptor is intact in mood disorders. Neuropsychopharmacology 12:263-268

Zhang H-Y, Ishigaki T, Tani K, Chen K, Shih JC, Miyasato K, Ohara K (1997): Serotonin ${ }_{2 A}$ receptor gene polymorphism in mood disorders. Biol Psychiat 41:768-773 